\title{
We can reduce the impact of scientific trawling on marine ecosystems
}

\author{
Trenkel Verena ${ }^{1,{ }^{*}}$, Vaz Sandrine ${ }^{2}$, Albouy Camille ${ }^{1}$, Brind'Amour Anik ${ }^{1}$, Duhamel Erwan ${ }^{1}$, \\ Laffargue Pascal $^{1}$, Romagnan Jean-Baptiste ${ }^{1}$, Simon Julien ${ }^{3}$, Lorance Pascal ${ }^{1}$ \\ ${ }^{1}$ Ifremer, 44311 Nantes Cedex 3, France \\ ${ }^{2}$ MARBEC, Univ Montpellier, CNRS, Ifremer, IRD, 34203 Sète Cedex, FRANCE \\ ${ }^{3}$ Ifremer, 56100 Lorient, France \\ *Corresponding author : Verena Trenkel, email address : verena.trenkel@ifremer.fr
}

\begin{abstract}
:
The negative impacts that scientific monitoring may have on marine ecosystems has been a neglected topic, mainly on the basis that its magnitude is minor compared to commercial fisheries, even though this raises ethical and, in certain cases, conservation issues. We argue that ethical principles should lead us to reconsider marine wildlife resource monitoring such as the fish and shellfish trawl surveys providing the science-based evidence needed for fisheries management and assessment of how environmental change impacts marine shelf communities worldwide. Recent scientific and technological progress has provided methods and tools which might now be harnessed to reduce the impact of marine monitoring. We review these alternative methods, consider modifications to current practices and identify areas requiring further research
\end{abstract}

Keywords: monitoring ethics; marine surveying; impacts of bottom trawling; genetic methods; ecosystem-based management 


\section{Ethics of monitoring}

Ethics deal with the moral principles that govern human behaviour in general or the conduct of a specific activity. Concerning marine living resources, ethics have been discussed in the scientific literature primarily with respect to wild-capture fisheries (Lam \& Pitcher 2012). A central issue of fishery ethics is fish welfare (Evans 2009, Metcalfe 2009, Diggles et al. 2011) as well as the social and wider ecosystem welfare (Lam \& Pitcher 2012). A much debated question in this context is whether or not fish can feel pain (Braithwaite 2010, Rose et al. 2014). The answer to this question determines acceptable human behaviour in particular from a consequentialist ethical point of view (consequentialism argues that the moral value of an action derives entirely from the value of its outcome).

Monitoring of living marine resources is an integral part of sustainable fisheries and ecosystem-based management. While the biodiversity, biomass extraction and sea floor impacts of many monitoring methods are, arguably, relatively minor compared to commercial fisheries, we need to consider whether the potential impacts are justified and unavoidable. We fully agree with Costello et al. (2016) that "scientific methods should minimise disturbance and stress to biodiversity, and any impacts should be explicitly justified". Thus while from a consequentialist ethical point of view the ends, fisheries management and assessment of how environmental change impacts marine shelf communities, might justify the means, trawl surveys, we argue that we should reduce monitoring impacts, if we can, without compromising the aims. The issue becomes acute if we acknowledge intrinsic rights (wellbeing, autonomy, justice) for all living beings, including animals. 


\section{Monitoring methods: trawling and alternatives}

Regular, large-scale scientific bottom trawl surveys underpin both stock assessments and the monitoring of the effects of fishing and environmental change on marine shelf communities worldwide (Figure 1). Similarly, many acoustic surveys use midwater trawling for species identification and size measurements. While certain species can survive hauling on board and subsequent return to the sea, many do not survive this treatment. In addition to killing many individuals, scientific trawling has a number of other potentially negative impacts on the marine ecosystem (Table 1). Realised impacts will, of course, depend on the actual survey protocol.

Recent scientific and technological progress has provided methods and tools which might help to make marine monitoring less harmful by reducing the need for bottom and mid-water trawling or providing ways for modifying trawling protocols. Below we review some of these alternative methods and practices and highlight areas requiring further research, but do not consider costs.

Visual methods are non-lethal and generally do not damage the habitat (see review in Mallet \& Pelletier 2014). They have proven useful for monitoring areas with high population densities such as coral reefs, mussel beds and Nephrops burrows, or habitats with sufficiently clear water. Recently, visual methods have been successfully applied to monitor mid-water pelagic fish (Boldt et al. 2018). In shallow waters, videos obtained from drones (unmanned aerial vehicle) have been used (Kiszka et al. 2016). Aerial surveys are routinely used to count juvenile Atlantic bluefin tuna (Bauer et al. 2015). However, visual methods suffer from drawbacks compared to trawl sampling: lower taxonomic resolution, restriction to clear water and small sampling volume, which makes the methods best suited for little mobile or sessile highly dense species and relatively small survey areas (Table 1). Recent progress applying automatic image analysis for counting and classifying fish species using deep learning techniques bears promise 
for the increased, routine use of visual methods as it overcomes time consuming manual video analysis (Siddiqui et al. 2018).

Fisheries acoustics offer the advantage of sampling a relatively large volume of water while generally requiring a relatively modest amount of fish sampling to ground truth species composition and fish length, and none for deriving a suite of ecosystem indicators (Trenkel et al. 2011). However, they are often limited to the pelagic realm as they still perform poorly in detecting fish close to the sea floor. Species identification using only acoustic data without trawling has been the focus of research for many decades (Horne 2000). Recent advances in acoustic methodology, in particular broadband techniques, are expected to allow some level of species discrimination without the need for trawl sampling but are unlikely to replace identification hauls for species which are acoustically identical (Bassett et al. 2018). Thus further research and development are needed before routine acoustic surveys can avoid identification hauls (Table 1).

Other alternative, non-lethal methods have been developed to monitor marine species but these are not yet routinely used. For example, open-codend trawls equipped with video systems bear promise for counting and measuring the size of mobile species (e.g. DeCelles et al. 2017). However, fine taxonomical determination of individuals on images and videos is not always possible due low system resolution or the orientation of animals in video images. For some species, specific morphological details needed for precise identification are not visible. Thus, even though there are restrictions on the taxonomic resolution that can be achieved, existing video-trawl systems effectively sample mobile individuals in the water column as well as near the sea floor. Hence open-codend trawls provide an operational alternative to bottom or midwater trawling for many mobile species (Table 1). 
For some rarer species where bottom trawl data are used (despite many shortcomings) for providing management advice (e.g. elasmobranch species in European waters), environmental DNA- (eDNA-) based methods analysing water samples or sediments might be useful (Kelly et al. 2014). Recent application of eDNA in aquatic habitats have confirmed the usefulness of this technique for determining species richness (Andruszkiewicz et al. 2017) including its seasonal variation (Sigsgaard et al. 2017), and for obtaining abundance proxies (Thomsen et al. 2016, Klobucar et al. 2017). There are many methodological pitfalls and challenges for eDNA related to sampling (contamination between samples), biomolecular analyses and bioinformatics (species resolution, genotyping errors, inhibition) and temporal and spatial scales (persistence and transport of DNA). However, the field is rapidly advancing and many issues will continue to be resolved, paving the way for eDNA to replace trawling in certain cases (Table 1). Similarly, DNA barcode analysis is a non-impacting method for estimating diet diversity from faeces (Guillerault et al. 2017).

As an alternative to abundance estimation based on counting animals (trawling, video, ...), markrecapture based methods, notably the recently developed close-kin mark recapture method using genetic-based identification of related individuals are promising alternatives for certain commercial species such as sharks, rays or tunas which can be sampled efficiently (Bravington et al. 2016a). The required sample size is proportional to $\sqrt{N}$, where $N$ is the number of adult individuals (Bravington et al. 2016b). Hence the feasibility of the method depends on sampling and genotyping costs. For this method, tissue samples can be collected on-board fishing vessels, or at fish auction markets, avoiding additional mortality through monitoring. In the future, the sex of individuals might also be determinable with appropriate DNA markers. The research needed for making close-kin mark-recapture a viable routine monitoring method concerns primarily the development of species-specific genetic markers, e.g. SNPs, and, depending on tissue sampling methods, ways to determine sex, maturity and age (Table 1). 
In many cases, dissecting individuals is the only feasible method for determining sex and maturity and, in these instances, non-lethal alternative methods are direly needed. Maturity and sex determination of these species based on blood sample analysis as currently applied in aquaculture and species of conservation concern (Mendoza et al. 2012) might be an option. DNA analysis might also provide indications of animal age, though currently this has only been tested for zebrafish (see review in De Paoli-Iseppi et al. 2017). Applying such methods would be a real step towards reducing trawl monitoring impacts, namely for species of conservation concerns such as elasmobranchs or for other species which can be released alive. Obviously, such an approach will do nothing for trawled or otherwise sampled individuals arriving dead or dying rapidly on board. To be useable in a monitoring context where many individuals might be sampled, cheap rapid test kits would need to be developed.

\section{Reducing trawling impacts}

To avoid disrupting long trawl survey time series by a change in observation method, improvements in survey design and deployment might exist which could reduce impacts (Table 1). The number of sampling stations (Figure 1) and swept area/volume per station directly determine the catch volume, hence the potential impact. Higher catch volumes can increase fish injury and subsequent mortality (Veldhuizen et al. 2018). Optimising survey design to reduce the number of hauls or trawl duration are potential options, but before implementing any changes it would be wise to evaluate potential side effects. Reducing haul duration entails the risk of reducing species richness as well as modifying sampled length and density estimates (Moriarty et al. 2018). The importance of the so called "end effect" (Battaglia et al. 2006) consisting of individuals caught during shooting and hauling will also be larger in shorter hauls, while the potential for trawl clogging will be reduced. Implementing handling methods that increase survival, such as keeping protected or fragile species in water while on board, should become standard practice on all surveys. 
Reducing habitat impacts of scientific trawling is another challenge. The physical impact of bottom trawls depends on the weight and structure of the trawl doors, as well as the use of chains, bobbins and other rigging (Moran \& Stephenson 2000). The development of scientific trawl gear can benefit from recent advances of commercial fishing gear (see review in McHugh et al. (2017)), as well as alternative catching devices (Table 1). Furthermore, the use of a cod-end closure system could ensure sampling only the intended depth layer instead of the entire water column, limiting the spatial scope of the impact while also improving the precision of the collected data.

Gear drag impacts fuel consumption (McHugh et al. 2017), hence the carbon footprint of scientific monitoring. Overall, there is likely room for reducing the carbon footprint by restructuring survey vessel fleets. This might be achievable by instead of relatively large multi-disciplinary vessels using a combination of smaller energy efficient vessels operating in tandem with autonomous platforms and remote sensing. For example, information on school densities and distributions in the upper layers of the ocean could be collected by airborne lidar (Churnside et al. 2011) or drones (Schaub et al. 2018). Optimal ways for combining several monitoring platforms requires further exploration.

Remains from fishing gears contribute significantly to the plastic pollution of the worlds' oceans (Eriksen et al. 2014). To minimise the contribution of monitoring gear to this pollution, the use of robust gear, less prone to releasing plastic material into the environment, or, on the contrary, the use of biodegradable gear materiel is an area requiring research, with commercial gear developments being already on the way (Kim et al. 2016). For example, recently the codend protection of the French survey bottom trawl was replaced by a rubber mat to reduce fibre pollution (Figure 2). 


\section{Conclusion}

Ethical considerations led us to comment on potential ways to reduce the impacts of scientific trawling as a method for monitoring living marine resources. As discussed here, this might require large changes, such as replacing survey vessels and observation technology (eDNA, open-codend video trawl, etc.), but also small, incremental modifications of current practices (reduced trawl duration, biodegradable gear material, etc.). The developments made to reduce the impacts of marine monitoring can be expected to yield solutions applicable to fisheries and other marine activities. Lastly, without needing new methods or any changes, including trawl survey catches systematically in total fishing quotas as already done in some countries (e.g. snow crab in Canada) would acknowledge the similarity of scientific and commercial fishing from an ethical point of view.

\section{Author contributions}

VT had the idea and collected the data; VT and PLo led the writing of the manuscript. All authors contributed critically to the drafts and gave final approval for publication.

\section{Acknowledgements}

We acknowledge funding from project GenoPopTaille (ANR-14-CE02-0006-01) and thank our colleagues for fruitful discussions during an internal working group. We are grateful to the reviewers for constructive comments.

\section{Supplementary information}

Supplementary information including one table with details on bottom trawl surveys in figure 1 can be found with this article online. 


\section{References}

Amante C, Eakins BW (2009) ETOPO1 1 Arc-Minute Global Relief Model: Procedures, Data Sources and Analysis. NOAA Technical Memorandum NESDIS NGDC-24 National Geophysical Data Center, NOAA

Andruszkiewicz EA, Starks HA, Chavez FP, Sassoubre LM, Block BA, Boehm AB (2017) Biomonitoring of marine vertebrates in Monterey Bay using eDNA metabarcoding. PLoS ONE 12

Bassett C, De Robertis A, Wilson CD (2018) Broadband echosounder measurements of the frequency response of fishes and euphausiids in the Gulf of Alaska. ICES Journal of Marine Science $75: 1131-1142$

Battaglia A, Trenkel VM, Rochet M-J (2006) Estimating end effects in trawl catches. ICES Journal of Marine Science 63:956-959

Bauer RK, Bonhommeau S, Brisset B, Fromentin JM (2015) Aerial surveys to monitor bluefin tuna abundance and track efficiency of management measures. Marine Ecology Progress Series $534: 221-234$

Boldt JL, Williams K, Rooper CN, Towler RH, Gauthier S (2018) Development of stereo camera methodologies to improve pelagic fish biomass estimates and inform ecosystem management in marine waters. Fisheries Research 198:66-77

Braithwaite V (2010) Do fish feel pain? Oxford University Press

Bravington MV, Grewe PM, Davies CR (2016a) Absolute abundance of southern bluefin tuna estimated by close-kin mark-recapture. Nature Communications 7

Bravington MV, Skaug HJ, Anderson EC (2016b) Close-Kin Mark-Recapture. Statistical Science 31:259-274 
Churnside JH, Sharov AF, Richter RA (2011) Aerial surveys of fish in estuaries: a case study in Chesapeake Bay. ICES Journal of Marine Science 68:239-244

Costello MJ, Beard KH, Corlett RT, Cumming GS, Devictor V, Loyola R, Maas B, Miler-Rushing AJ, Pakeman R, Primack RB (2016) Field work ethics in biological research. Biological Conservation 203:268-271

De Paoli-Iseppi R, Deagle BE, McMahon CR, Hindell MA, Dickinson JL, Jarman SN (2017) Measuring Animal Age with DNA Methylation: From Humans to Wild Animals. Frontiers in Genetics 8

DeCelles GR, Keiley EF, Lowery TM, Calabrese NM, Stokesbury KDE (2017) Development of a video trawl survey system for New England groundfish. Transactions of the American Fisheries Society 146:462-477

Diggles BK, Cooke SJ, Rose JD, Sawynok W (2011) Ecology and welfare of aquatic animals in wild capture fisheries. Reviews in Fish Biology and Fisheries 21:739-765

Eriksen M, Lebreton LCM, Carson HS, Thiel M, Moore CJ, Borerro JC, Galgani F, Ryan PG, Reisser J (2014) Plastic Pollution in the World's Oceans: More than 5 Trillion Plastic Pieces Weighing over 250,000 Tons Afloat at Sea. PLoS ONE 9

Evans JC (2009) The ethics of fish welfare. Journal of Fish Biology 75:2872-2874

Guillerault N, Bouletreau S, Iribar A, Valentini A, Santoul F (2017) Application of DNA metabarcoding on faeces to identify European catfish Silurus glanis diet. Journal of Fish Biology 90:2214-2219

Horne JK (2000) Acoustic approaches to remote species identification: a review. Fisheries Oceanography 9:356-371

Kelly RP, Port JA, Yamahara KM, Martone RG, Lowell N, Thomsen PF, Mach ME, Bennett M, Prahler E, Caldwell MR, Crowder LB (2014) Harnessing DNA to improve environmental management. Science 344:1455-1456 
Kim S, Kim P, Lim J, An H, Suuronen P (2016) Use of biodegradable driftnets to prevent ghost fishing: physical properties and fishing performance for yellow croaker. Animal Conservation 19:309319

Kiszka JJ, Mourier J, Gastrich K, Heithaus MR (2016) Using unmanned aerial vehicles (UAVs) to investigate shark and ray densities in a shallow coral lagoon. Marine Ecology Progress Series 560:237-242

Klobucar SI, Rodgers TW, Budy P (2017) At the forefront: evidence of the application of using environmental DNA to quantify the abundance of fish populations in natural lentic waters with additional sampling considerations. Canadian Journal of Fisheries and Aquatic Science 74:20302034

Lam ME, Pitcher TJ (2012) The ethical dimensions of fisheries. Current Opinion in Environmental Sustainability 4:364-373

Mallet D, Pelletier D (2014) Underwater video techniques for observing coastal marine biodiversity: A review of sixty years of publications (1952-2012). Fisheries Research 154:44-62

McHugh MJ, Broadhurst MK, Sterling DJ (2017) Choosing anterior-gear modifications to reduce the global environmental impacts of penaeid trawls. Reviews in Fish Biology and Fisheries 27:111134

Mendoza R, Santillalan O, Revol A, Aguilera C, Cruz J (2012) Alligator gar (Atractosteus spatula, Lacepede 1803) vitellogenin: purification, characterization and establishment of an enzymelinked immunosorbent assay. Aquaculture Research 43:649-661

Metcalfe JD (2009) Welfare in wild-capture marine fisheries. Journal of Fish Biology 75:2855-2861 
Moran MJ, Stephenson PC (2000) Effects of otter trawling on macrobenthos and management of demersal scalefish fisheries on the continental shelf of north-western Australia. ICES Journal of Marine Science 57:510-516

Moriarty M, Sell AF, Trenkel VM, Lynam C, Burns F, Clarke ED, Greenstreet SPR, McGonigle C (2018) Resolution of biodiversity and assemblage structure in demersal fisheries surveys: the role of tow duration. ICES Journal of Marine Science doi:10.1093/icesjms/fsy050

Rose JD, Arlinghaus R, Cooke SJ, Diggles BK, Sawynok W, Stevens ED, Wynne CDL (2014) Can fish really feel pain? Fish and Fisheries 15:97-133

Schaub J, Hunt BPV, Pakhomov EA, Holmes K, Lu YH, Quayle L (2018) Using unmanned aerial vehicles (UAVs) to measure jellyfish aggregations. Marine Ecology Progress Series 591:29-36

Siddiqui SA, Salman A, Malik MI, Shafait F, Mian A, Shortis MR, Harvey ES (2018) Automatic fish species classification in underwater videos: exploiting pre-trained deep neural network models to compensate for limited labelled data. ICES Journal of Marine Science 75:374-389

Sigsgaard EE, Nielsen IB, Carl H, Krag MA, Knudsen SW, Xing YC, Holm-Hansen TH, Moller PR, Thomsen PF (2017) Seawater environmental DNA reflects seasonality of a coastal fish community. Marine Biology 164

Thomsen PF, Moller PR, Sigsgaard EE, Knudsen SW, Jorgensen OA, Willerslev E (2016) Environmental DNA from Seawater Samples Correlate with Trawl Catches of Subarctic, Deepwater Fishes. PLoS ONE 11

Trenkel VM, Ressler PH, Jech M, Giannoulaki M, Taylor C (2011) Underwater acoustics for ecosystembased management: state of the science and proposals for ecosystem indicators. Marine Ecology Progress Series 442:285-301 
Veldhuizen LJL, Berentsen PBM, de Boer IJM, van de Vis JW, Bokkers EAM (2018) Fish welfare in capture fisheries: A review of injuries and mortality. Fisheries Research 204:41-48 
Table1. Overview of observation methods potentially useable for monitoring marine living resources and their impacts (non exhaustive list). For trawling, research needs concern ways for reducing impacts while for all other methods the progress needed to use method in replacement of trawling is listed.

\begin{tabular}{|c|c|c|c|c|}
\hline $\begin{array}{l}\text { Observation } \\
\text { method }\end{array}$ & Type of information & Target species & Impacts & Research needs \\
\hline trawling & $\begin{array}{l}\text { By species } \\
\text { - } \text { abundance/biomass } \\
\text { - diet } \\
\text { - individual traits (size, sex, } \\
\text { maturity, age,...) }\end{array}$ & $\begin{array}{l}\text { - demersal fishes \& } \\
\text { invertebrates } \\
\text { - benthic fishes \& invertebrates } \\
\text { - pelagic fishes }\end{array}$ & $\begin{array}{l}\text { - } \text { animal handling } \\
\text { - } \text { mortality } \\
\text { - } \text { habitat modification } \\
\text { - } \text { lost gear material } \\
\text { emission, ...) }\end{array}$ & $\begin{array}{l}\text { - optimal survey design to reduce } \\
\text { trawl duration/ catches } \\
\text { - on board catch handling } \\
\text { procedure to increase survival } \\
\text { - trawl rigging modifications to } \\
\text { reduce habitat impact } \\
\text { - trawl material to reduce plastic } \\
\text { pollution }\end{array}$ \\
\hline video/photo & $\begin{array}{l}\text { By species/group } \\
\text { - } \quad \text { abundance/biomass } \\
\text { - } \quad \text { size (e.g. stereo method) }\end{array}$ & $\begin{array}{l}\text { - demersal fishes \& } \\
\text { invertebrates } \\
\text { - benthic fishes \& invertebrates } \\
\text { in clear water and small survey } \\
\text { area or at high density }\end{array}$ & $\begin{array}{l}\text { - } \quad \text { animal reaction behaviour } \\
\text { - } \text { platform (noise, greenhouse gas } \\
\text { emission,...) }\end{array}$ & $\begin{array}{l}\text { - optimal survey } \\
\text { design/combination of methods to } \\
\text { increase survey area and species } \\
\text { covered } \\
\text { - estimation } \\
\text { observability/behaviour effects } \\
\text { - automatic image analysis }\end{array}$ \\
\hline acoustics & $\begin{array}{l}\text { By “acoustic" species } \\
\text { - abundance/biomass } \\
\text { - } \quad \text { size if species known }\end{array}$ & $\begin{array}{l}\text { - } \quad \text { pelagic fishes } \\
\text { - } \text { semi-demersal fishes }\end{array}$ & $\begin{array}{l}\text { - platform (noise, greenhouse gas } \\
\text { emission, ...) }\end{array}$ & $\begin{array}{l}\text { - } \quad \text { species identification without } \\
\text { trawling } \\
\text { - } \quad \text { size estimation without trawling }\end{array}$ \\
\hline video trawl & $\begin{array}{l}\text { By species/group } \\
\text { - } \quad \text { abundance } \\
\text { - } \quad \text { size }\end{array}$ & $\begin{array}{ll}\text { - } & \text { pelagic fishes } \\
\text { - } & \text { demersal fishes }\end{array}$ & $\begin{array}{l}\text { - animal herding } \\
\text { - vessel (noise, greenhouse gas } \\
\text { emission...) }\end{array}$ & - automatic image analysis \\
\hline $\begin{array}{l}\text { environmental } \\
\text { DNA }\end{array}$ & $\begin{array}{l}\text { By location } \\
\text { - number of species }\end{array}$ & - all species & $\begin{array}{l}\text { - platform (noise, greenhouse gas } \\
\text { emission,...) }\end{array}$ & $\begin{array}{l}\text { - development of quantitative } \\
\text { DNA approach as abundance proxy }\end{array}$ \\
\hline $\begin{array}{l}\text { close-kin } \\
\text { mark- } \\
\text { recapture }\end{array}$ & $\begin{array}{l}\text { By population } \\
\text { - } \quad \text { spawner abundance } \\
\text { - } \quad \text { total mortality rate }\end{array}$ & $\begin{array}{l}\text { - fish \& invertebrates, e.g. } \\
\text { elasmobranchs }\end{array}$ & $\begin{array}{lll}\text { tissue } & \text { sampling } & \text { method } \\
\text { dependent }\end{array}$ & $\begin{array}{l}\text { - genetic markers for most } \\
\text { species } \\
\begin{array}{l}\text { genetic sex, maturity \& age } \\
\text { determination }\end{array}\end{array}$ \\
\hline
\end{tabular}


Figure legends

Figure 1. Overview of locations and intensity of major regular ongoing scientific marine bottom trawl surveys for fisheries management. Bubble diameter is proportional to the mean number of annual trawl stations (see Supplementary information table S1 for details). Brown lines identify coastlines and areas of these surveys instead of actual survey areas. Green lines identify coastlines and areas of other trawl surveys, stopped, discontinued or data unavailable. The map background represents the world bathymetry extract from Etopo1 (Amante \& Eakins 2009 ).

Figure 2. Onboard RV Thalassa the codend protective layer made of polyethylene twine (left) has been replaced by a rubber mat (right) in an attempt to reduce plastic fibre pollution.

Photo left: Ifremer -Séverine TOURBOT-PAUL; photo right Ifremer- Vincent BADTS. 


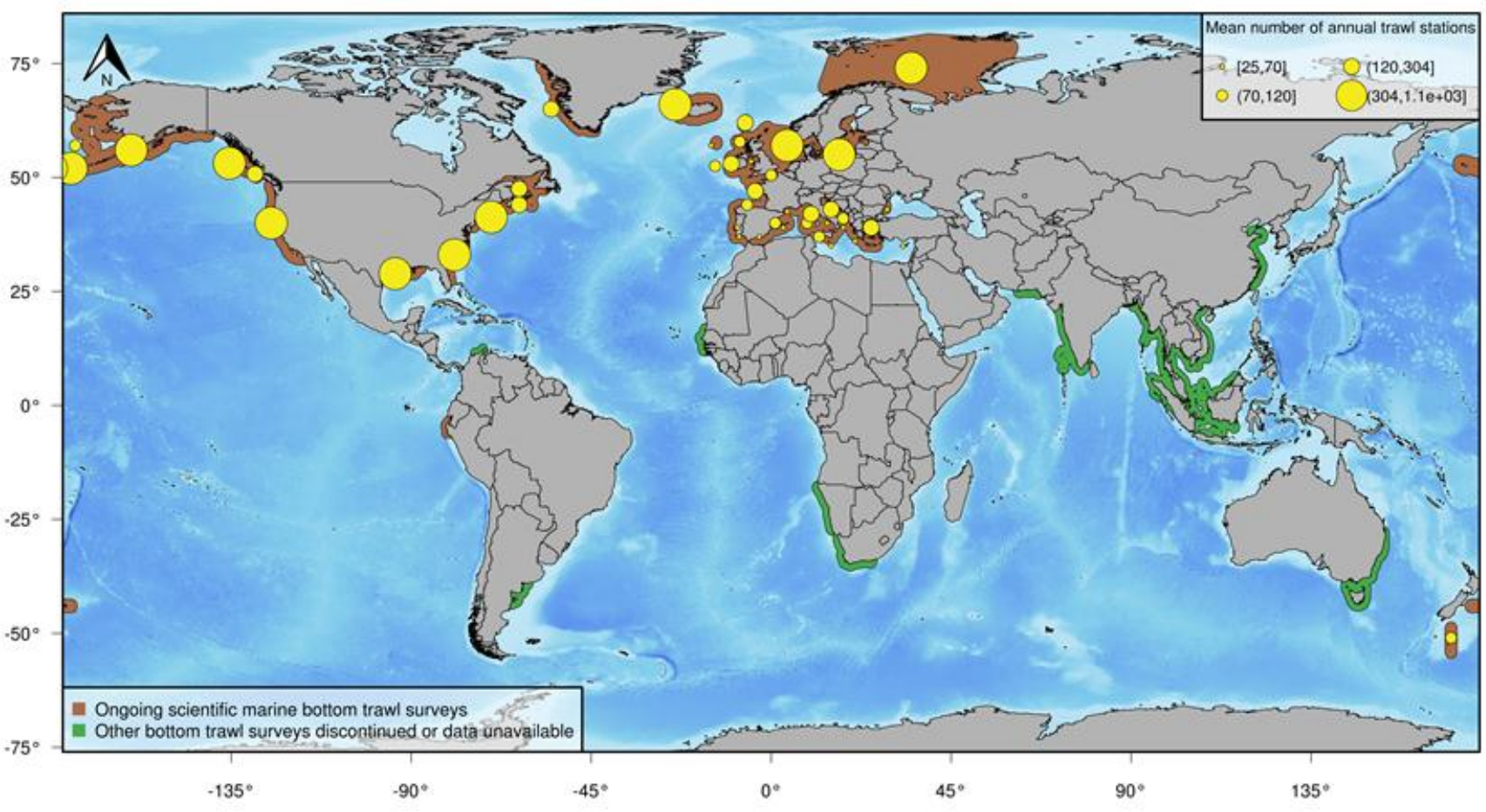

Figure 1. Overview of locations and intensity of major regular ongoing scientific marine bottom trawl surveys for fisheries management. Bubble diameter is proportional to the mean number of annual trawl stations (see Supplementary information table S1 for details). Brown lines identify coastlines and areas of these surveys instead of actual survey areas. Green lines identify coastlines and areas of other trawl surveys, stopped, discontinued or data unavailable. The map background represents the world bathymetry extract from Etopo1 (Amante \& Eakins 2009 ). 


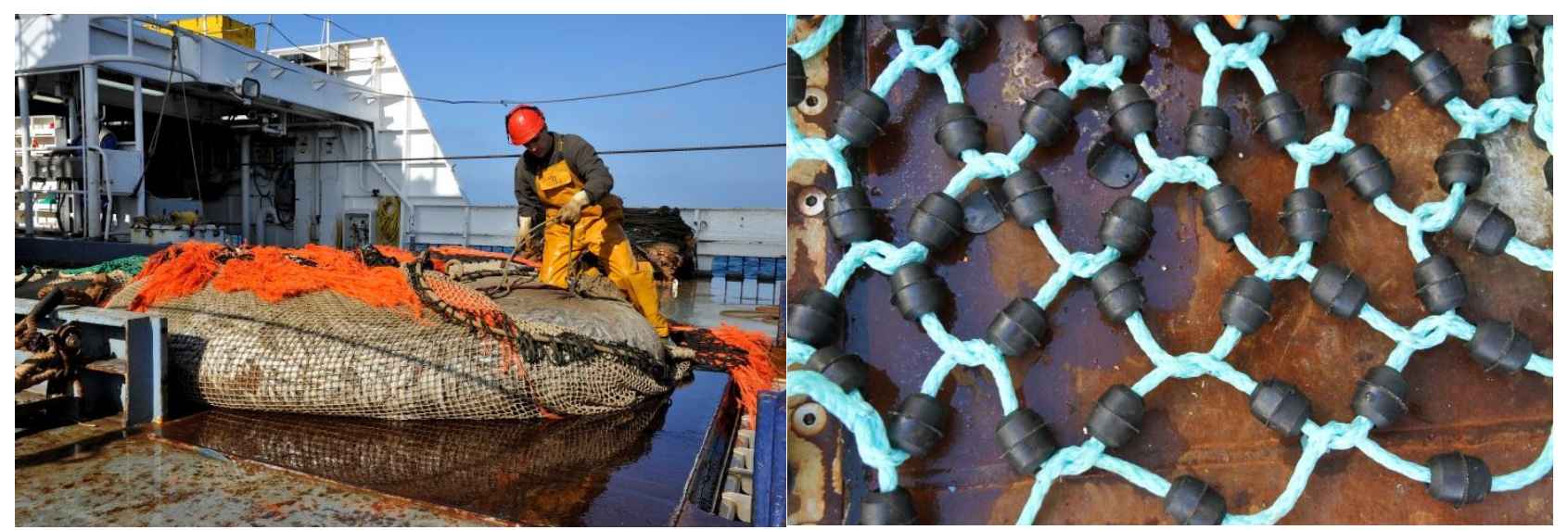

Figure 2. Onboard RV Thalassa the codend protective (orange) layer made of polyethylene twine (left) has been replaced by a rubber mat (right) to reduce plastic fibre pollution.

Photo left: Ifremer-Séverine TOURBOT-PAUL; photo right Ifremer-Vincent BADTS. 